\title{
Durf ons nog preek dat werk 'n roeping van God is?
}

\author{
Etienne de Villiers \\ Departement Dogmatiek en Christelike Etiek \\ Universiteit van Pretoria
}

\begin{abstract}
Is the preaching that work is a vocation of God still relevant?

According to the view of the Reformers Luther and Calvin work is a vocation of God. This article attemps to establish whether this view is still valid today. A number of factors that contribute to presentday Christians experiencing this view as problematical, are discussed. As a result of this experience the theologian Miroslav Volf argues that the Reformed view of work as a vocation of God should be relinquished. Contrary to Volf, the author of the article argues that the view of the Reformers can and should be retained. A more dynamic interpretation of work as vocation of God should, however, be given and the comprehensive theological framework within which the Bible views work, should be respected.
\end{abstract}

\section{INLEIDING}

Werk neem 'n belangrike plek in ons lewens in. Dit neem 'n groot gedeelte van ons wakker ure in beslag. Dit wat ons verdien deur ons werk, bepaal watter soort bestaan ons kan voer. Die soort werk wat ons doen en die soort mense met wie ons in ons werk te doen het, druk 'n stempel af op ons persoonlike identiteit. Reeds om dié redes sou 'n mens verwag dat daar baie aandag aan werk in prediking gegee sou word.

Daar is nog 'n rede waarom 'n mens sou verwag dat prediking oor werk in veral Protestantse kerke 'n sentrale plek sou inneem. Een van die onmiskenbare erfenisse van die Hervorming in die $16 \mathrm{e}$ eeu is dat werk 'n roeping van God is. Die Rooms-Katolieke Kerk het tot op daardie stadium in aansluiting by die Griekse filosofie geleer het dat die lewe van besinning (die "vita contemplativa") belangriker is as die werklewe (die "vita activa"). Slegs die priesters en die monnike het volgens die Rooms-Katolieke Kerk van God 'n geestelike roeping ontvang en slegs hulle lewe van geestelike afsondering en toewyding is as heilig beskou. Luther, en in navolging van hom Calvyn, het 
egter die radikale boodskap verkondig dat alle werk 'n roeping van God is. Die geestelike roeping (vocatio spiritualis) om 'n Christen te word en as Christen te leef, loop volgens hulle uit op 'n uitwaartse roeping (vocatio externa) ten aansien van die werk waarin gelowiges staan. ${ }^{1}$

Die Hervormers se standpunt hou eerstens in dat gewone gelowiges se wêreldlike aktiwiteite op grond van hulle roeping deur God godsdienstige betekenis het. Nie eers as hulle geestelike werk doen nie, maar reeds as hulle hulle daaglikse werk verrig, lewer hulle diens in God se koninkryk. Tweedens hou dit in dat die pligte en verpligtinge wat met hulle sosiale rolle en sosiale stand gepaard gaan, positief met God se wil in verband gebring word. Hulle hoef dus nie huis en haard te verlaat om God se wil te doen nie. Hulle is reeds gehoorsaam aan sy wil as hulle pligsgetrou die daaglikse werk doen wat aan hulle op grond van hulle stand toebedeel is. Derdens het dit beteken dat teologiese legitimiteit aan nie net die gesag van die predikant nie, maar aan ampsdraers in die samelewing, soos regeringsleiers, regters, onderwysers, werkgewers en ouers verleen is. Hulle almal is geroep om juis in die uitoefening van hulle ampte verteenwoordigers van God te wees (vgl Schuurman 2001:52-56).

Ten spyte daarvan dat werk in die lewe van die meeste van ons 'n belangrike plek inneem en dat die oortuiging dat gelowiges hulle roeping deur God juis in hulle daaglikse werk uitleef 'n Protestantse erfenis is, word daar vandag maar bitter weinig oor werk gepreek. Waarom is dit die geval? Dit is nie maklik om op hierdie vraag 'n antwoord te gee nie. Een ding is egter duidelik: dit is nie omdat lidmate so oortuig is daarvan dat hulle daaglikse werk 'n roeping van God is en so presies weet hoe hulle hulle goddelike roeping in hulle werk moet uitleef dat hulle nie prediking oor die onderwerp benodig nie. Die teendeel is eerder die geval: lidmate - maar ook hulle predikante - ervaar die standpunt van die Hervormers as 'n verleentheid en 'n probleem. Lidmate weet dikwels nie meer hoe hulle hulle goddelike roeping in hulle daaglikse werk kan uitleef nie. Selfs: hulle ervaar dikwels nie meer hulle daaglikse werk as roeping van God nie. Dit is vir hulle baie makliker om hulle roeping as 'n suiwer geestelike roeping te sien wat hulle in geestelike en kerklike werk kan uitleef. ${ }^{2}$

\footnotetext{
${ }^{1} \mathrm{Vgl}$ vir ' $\mathrm{n}$ bespreking van die Hervormers se siening van werk as roeping van God: Forrester (1951:146-151); Grenholm (1993:41-50); Nelson (1954:106-111); Schuurman (2001:51-56); Smit ( 2001:12-17); Stevens (1999:77-80); Task Force PCUSA (1990:47-50); Volf (1991:10516).

${ }^{2}$ Vir 'n bespreking van die faktore wat bydra tot die problematisering van die traditioneel Protestantse siening van werk, onder andere, kyk Grenholm (1993); Preece (1995); Smit (2001); Stevens (1999); Vischer (1996); Volf (1991).
} 
'n Mens kan vandag nie op 'n verantwoorde wyse oor prediking oor werk skryf sonder om aandag te gee aan die problematisering van die Hervormers se standpunt dat werk 'n roeping van God is nie. Daarom word eers 'n aantal faktore aan die orde gestel wat tot hierdie problematisering bygedra het. Daarna word die onvermydelike vraag gekonfronteer: moet ons vandag nog vashou aan die standpunt dat werk 'n roeping van God is? Die antwoord op hierdie vraag - so glo ek - is dat ons nog steeds daaraan moet vashou, maar dan op 'n gewysigde en gekwalifiseerde wyse. In 'n laaste deel word 'n aantal riglyne vir prediking oor werk geformuleer waarin gepoog word om reg te laat geskied aan sowel die Bybelse boodskap oor werk, as die huidige situasie in die werkplek en die eise wat dit aan lidmate stel.

\section{FAKTORE WAT DIE BELEWING VAN WERK AS ROEPING VAN GOD KORTWIEK}

Tussen die optrede van die Hervormers en die hede lê 'n aantal eeue wat gekenmerk is deur die proses van modernisering wat 'n ongekende ingrypende invloed op die werkplek en ook op opvattinge oor werk uitgeoefen het. Onder modernisering kan ons die maatskaplike ontwikkeling verstaan wat gekenmerk word deur die strewe om probleme uitsluitlik met behullep van die rede op te los. Hierdie ontwikkeling het nie net daartoe gelei dat samelewingsverbande soos die ekonomie en die politiek hulle al meer losgemaak het van die invloed van die godsdiens en dus gesekulariseerd geraak het nie, maar het ook die grootskaalse interne rasionalisering van hierdie samelewingsverbande tot gevolg gehad. Kenmerkend van byvoorbeeld ekonomiese modernisering is: skeiding van ekonomie en gesin, rasionele boekhouding, effektiewe benutting van kapitaal deur investering, effektiewe benutting van arbeidskragte en die metodiese gebruikmaking van wetenskaplike en tegnologiese kennis. ${ }^{3}$

Enkele van die ontwikkelinge wat met die proses van modernisering saamhang en 'n stremmende uitwerking op die opvatting van werk as 'n roeping van God gehad het, is die volgende:

- $\quad$ Die opvatting van werk as roeping van God het mettertyd volledig gesekulariseerd geraak (vgl Smit 2001:17-22; Preece 1995:9-10,190192; Task Force PCUSA 1990:51-53; Volf 1991:46-65). Die standpunt van Luther dat kerklidmate as Christene, dit wil sê in bewustelike gehoorsaamheid en trou aan God en sy wil, geroep is om hulle werk te doen, het mettertyd in die Westerse wêreld verander in die standpunt

\footnotetext{
${ }^{3} \mathrm{~J}$ A van der Ven (1993:17-26) bied 'n kernagtige dog indringende bespreking van die verskillende dimensies van modernisering in sy boek Ecclesiologie in context.
} 


\section{Durf ons nog preek dat werk 'n roeping van God is?}

dat alle mense 'n roeping het om pligsgetrou te werk. Wat oorgebly het, is slegs die assosiasies van die besondere belang van werk en die plig tot hardwerkendheid. Van die sogenoemde "Protestantse werketiek" wat aanvanklik ingebed was in 'n raamwerk van Christelike oortuiginge, het nog slegs 'n gesekulariseerde ideologie van werketiek behoue gebly wat daarvan uitgaan dat dit werk is waardeur ons tot selfverwesenliking kom, wat aan die lewe betekenis en aan ons 'n gevoel van identiteit en selfwaarde gee en boonop aan ons en andere voorspoed kan verseker. In die lig van dié heersende ideologie van werketiek wat as kernoortuiging het dat dit werk is wat uiteindelik saakmaak, kan die huiwering van predikante om al te geredelik lidmate daaraan te herinner dat werk ' $n$ roeping van God is, verstaan word. Prediking oor werk as roeping van God kan maklik lei tot die legitimering van die hedendaagse ideologie van werketiek. 'n Mens kan ook verstaan dat lidmate wat in die werkplek gedurig onderwerp word aan die aanwending van hierdie ideologie om werknemers tot nog groter insette en produktiwiteit aan te wakker, nie juis daarna uitsien om weer Sondag te verneem dat dit die wil van God is dat hulle hulle werk pligsgetrou moet doen nie!

- "Werk" het vandag feitlik sinoniem geword vir "betaalde indiensneming" (Preece 1995:233-264; Stott 1990:180). Dit was beslis nog nie die geval by Luther nie. Werk het vir hom 'n baie wyer betekenis gehad. Dit was vir hom die vervulling van die pligte wat met iemand se stand of posisie in die samelewing saamgehang het. Aangesien elkeen van God 'n roeping ontvang het om die pligte van die stand waartoe hulle behoort na te kom, was na sy mening niemand, of dit nou 'n boer, huisvrou of onvolwasse kind was, sonder 'n sekere vorm van werk nie. Tydens die moderniseringsproses is werk in nywerhede en besighede steeds meer rasioneel georden in hiërargiese postestrukture met korresponderende vergoedingspakette. Om te werk het al meer geassosieer geraak met die bekleding van so 'n betaalde pos. Om nie 'n betaalde pos te hê nie, beteken vandag dat 'n mens as werklose geklassifeer word. Aangesien status in die samelewing ook ten nouste korreleer met die posvlak wat beklee word en die salaris wat verdien word, hou werkloosheid besonder negatiewe konsekwensies vir 'n persoon se status en ook selfbeeld in. Om in hedendaagse samelewings, waarin werk feitlik uitsluitlik op betaalde werk dui, op 'n ongekwalifiseerde wyse die boodskap dat werk 'n roeping van God is, te verkondig, kan verder bydra tot die elende van die groot aantal mense wat nie ' $n$ betaalde werk kan kry nie, of nie in die posisie is om 
betaalde werk te doen nie, weens die feit dat hulle ander verantwoordelikhede, soos die grootmaak van kinders, het.

- $\quad$ Die werk wat mense vandag doen, het dikwels 'n vervreemdende uitwerking (Schuurman 2001:56-60; Volf 1991:157-201). Die tyd van Luther is gekenmerk deur ' $n$ huishoudsekonomie. Daar is direk met ander mense handel gedryf met produkte wat meestal self verbou of vervaardig is. Dit was dus nie moeilik vir Christene van destyds om hulle met Luther se standpunt dat werk 'n roeping van God is, te vereenselwig nie. Hulle kon duidelik ervaar dat hulle deur hulle werk diens aan hulle medemens en daarmee ook aan God lewer. As gevolg van toenemende spesialisering het baie werkers vandag geen persoonlike interaksie met die mense wat uiteindelik die produk wat hulle vervaardig, benut nie. Hulle sien dikwels nie eens die klaar produk waarvan hulle 'n onderdeel vervaardig nie. Hulle is dus in 'n dubbele sin in hulle werk vervreem: van medemense en van die produk van hulle werk. Van dié werk het daarby 'n sterk repeterende en afstompende aard. Waar dit in die onlangse verlede veral die geval was met werk wat aan die lopende band in 'n fabriek gedoen word, is dit vandag ook die geval met sekere vorme van dataprosessering. Vir mense wat sulke werk doen, is dit baie moeilik om hulle werk as roeping van God te verstaan.

- $\quad$ Die waardes wat vandag in die werkplek geld, is dikwels nie te rym met Christelike waardes nie. Deel van Luther se siening was dat Christene hulle werk in ooreenstemming met die wet van God moet doen. In die verselfstandige lewensverbande van ons tyd is daar dikwels geen plek vir Christelike waardes nie. In ooreenstemming met Adam Smith se leer van die "verborge hand" behoort 'n individu in die vrye mark sy eie belang na te streef, omdat juis dit daartoe lei dat die algemene welsyn in die samelewing gedien word. ${ }^{4}$ Die kompetisiedruk in besighede is soms so groot dat van werknemers verwag word om minderwaardige en selfs onveilige produkte te verkoop, of om die boeke te kook. ${ }^{5}$ Dit is nie vir Christen-werknemers van wie verwag word om hulle werk in

\footnotetext{
${ }^{4} \mathrm{Vgl}$ vir 'n bespreking van die mites wat met hierdie heersende oortuiging in die besigheidswêreld saamhang D Rossouw se Business ethics in Africa (2002), 11-23.

${ }^{5}$ Vir 'n bespreking van die negatiewe invloed van wat hy "savage capitalism" noem op die hedendaagse werkplekkultuur, kyk R N Bellah (1990) se Discipleship and citizenship in the workplace. Bellah haal in dié verband die voormalige president van Tjeggoslowakye, Vaclac Havel aan: "We still don't know how to put morality ahead of politics, science and economy. We are still incapable of understanding that the only genuine backbone of all our actions is responsibility, responsibility to something higher than my family, my country, my company, my success" (2-3).
} 
stryd met Christelike waardes te doen, moontlik om hulle werk as diens aan God te beskou nie.

Hierdie faktore maak dit vir 'n prediker vandag moeilik om op 'n oortuigende en ongekompliseerde wyse die Christelike boodskap van werk as roeping van God oor te dra, sonder om in die proses gesekulariseerde ideologieë oor werk te legitimeer. Dit bring ook teweeg dat lidmate emosioneel 'n weerstand teen die tematisering van werk in die prediking opbou. Hulle het eerder 'n behoefte aan volledige ontvlugting van die werkplek en die stres in die godsdienstige belewing wat gesamentlike aanbidding bied. Die verwagting wat hulle van die erediens het, is dat dit hulle sal help om tot verhaal te kom voordat hulle 'n nuwe spanningsvolle werkweek aanpak, eerder as dat dit hulle sal toerus om as Christene die uitdagings wat die werkplek bied te kan hanteer.

Hierdie instelling lei op sy beurt daartoe dat selfs Protestantse lidmate en predikante vandag - ironies genoeg - weer al meer daartoe begin neig om hulle roeping van God as suiwer geestelik te verstaan. Hulle voel hulle uitsluitlik geroepe om betrokke te raak by tipies kerklike aktiwiteite en geestelike werk soos sendingwerk onder nie-Christene en evangelisasiewerk onder kerkafvalliges. Indien hulle enigsins hulle werkplek met hulle roeping in verband bring, is dit omdat hulle die werkplek as nog 'n geleentheid tot sending- of evangelisasiewerk onder ongelowige mense beskou (vgl Stott 1990:165).

Die gevolg van dit alles is dat baie hedendaagse Christene geensins hulle daaglikse werk positief met hulle geloof in verband bring nie. Hulle handhaaf prakties 'n streng Twee Rykeleer: hulle kerk en hulle persoonlike verhoudinge is die plek waar hulle hulle geestelike roeping as kinders van God uitleef en waar hulle probeer om die morele eise van die Bybel uit te leef; hulle werk is die plek waar hulle hulle daaglikse brood verdien en waar heeltemal ander spelreëls geld. Vir sommige Christene is hierdie skerp tweedeling nou maar eenmaal soos die lewe is. Hulle kan gemaklik daarmee saamleef en laat nie toe dat dit vir hulle enige gewetenswroeging veroorsaak nie. Ander ervaar wel 'n spanning tussen die twee lewes wat hulle voer en die teenstrydige waardestelsels wat daarin geld. Aangesien hulle dit egter nie kan vermy om te werk nie, beskou hulle hulle werk as 'n noodsaaklike euwel (Stott 1990:164-166). 


\section{MOET ONS VASHOU AAN DIE STANDPUNT DAT WERK 'N ROEPING VAN GOD IS?}

In die lig van die genoemde probleme wat vandag ervaar word met die standpunt dat werk ' $n$ roeping van God is, gaan daar al meer stemme op dat ons dié standpunt moet laat vaar. 'n Leidinggewende stem in dié verband is die Kroaties gebore teoloog Miroslav Volf. ${ }^{6} \mathrm{Hy}$ bied die volgende argumente teen die handhawing van Luther se beskouing (Volf 1991:106-109):

- $\quad$ Luther se beskouing staan onverskillig teenoor vervreemding in die werk. Dit is slegs die oorsprong en doel van werk wat vir Luther roeping definieer en nie die kwaliteit daarvan nie. Elke werk is dus per definisie 'n roeping van God, maak nie saak hoe ontmenslikend dit ook al is nie.

- Daar is 'n gevaarlike dubbelsinnigheid in Luther se beskouing van roeping. Hy onderskei wel die geestelike roeping deur die verkondiging van die evangelie van die uitwaartse vergestalting van dié roeping in werk. Hy dui egter nie aan hoe spanninge tussen dié twee vorme van die roeping opgelos moet word nie. In die geskiedenis van die Lutheranisme was daar steeds weer die neiging om sulke spanninge op te los deur die geestelike roeping te integreer met en so voorrang te verleen aan die pligte wat met die beroep saamhang.

- $\quad$ Die beskouing van werk as roeping kan maklik ideologies misbruik word. Selfs die mees ontmenslikende werk kan voorgehou word as diens aan God en werknemers kan in die naam van die Here opgeroep word om nog harder te werk.

- $\quad$ Die begrip roeping is nie toepaslik in die toenemend mobiele nywerheids- en inligtingssamelewing nie. Luther ontleen aan die enkelvoudigheid en permanensie van die geestelike roeping tot God se koninkryk sy beskouing dat werk as roeping van God die plig inhou om te volhard met die werk wat hoort by jou stand. Vandag het ons egter nie net te doen met die feit dat baie mense gedurende hulle lewe 'n hele verskeidenheid poste ná mekaar beklee nie (diachroniese pluraliteit van indiensneming), maar ook dikwels meer as een pos tegelyk beklee (sinchroniese pluraliteit van indiensneming).

\footnotetext{
${ }^{6}$ Vir 'n kritiese bespreking van die siening dat werk 'n roeping van God is en die optimistiese siening van werk wat vandag nog, as gevolg daarvan, in die meeste kerke heers, kyk ook L Vischer, Arbeit in der Krise (1996).
} 
Volf meen dat ons nie moet probeer om die beskouing van werk as roeping van God te herinterpreteer om voorsiening te maak vir hedendaagse werksomstandighede nie. Eerstens stem eksegete saam dat Luther die Bybelse teks wat hy ter ondersteuning van sy beskouing aanhaal, 1 Korintiërs 7:20, verkeerd geïnterpreteer het. Die roeping waarvan in dié teks sprake is, is nie die roeping waarmee, waartoe of waardeur 'n mens geroep word nie soos Luther gemeen het - maar verwys na die situasie waarin hy of sy is wanneer hulle geroep word om 'n Christen te word. Tweedens maak dit teologies slegs sin om werk as uitwaartse roeping te verstaan as 'n mens dié roeping na analogie van die geestelike roeping om Christen te wees, kan verstaan. In die hedendaagse mobiele samelewing is dit egter onmoontlik om aan die roeping tot werk 'n dergelike enkelvoudigheid en permanensie as aan die geestelike roeping toe te ken (Volf 1991:109-111).

Volf stel voor dat ons die begrip roeping in verband met werk vervang met 'n ander Bybelse begrip wat, na sy mening, meer reg laat geskied aan die dinamiese karakter van hedendaagse werk, naamlik charisma of gawe. Die begrip roeping dui dan uitsluitlik op die algemene roeping wat van die verkondiging uitgaan om die koninkryk van God in te gaan en te leef as 'n gelowige, soos dit deurgaans in die Nuwe Testament die geval is. Hierdie roeping word vir alle gelowiges konkreet in die roeping om die vrugte te dra van die Gees. Aangesien hulle egter in 'n verskeidenheid situasies geplaas word, vertak die roeping om in ooreenstemming met die koninkryk te lewe in 'n verskeidenheid gawes aan elke individuele gelowige (Volf 1991:111-117).

Die vraag of die beskouing van werk as roeping van God nog gehandhaaf moet word, kan nie slegs op eksegetiese gronde beslis word nie. Wat beslissend is, is nie of Luther "die roeping waarin iemand geroep word" (letterlike vertaling uit die Grieks) van 1 Kor. 7:20 reg geïnterpreteer het toe hy dit as roeping om in die beroep te bly waarin iemand was, verstaan het nie. Die beslissende vraag is eerder of hy teologies reg was om die beskouing van die roeping om Christen te word en te wees as 'n roeping tot slegs geestelike of godsdienstige aktiwiteite, af te wys en daarteenoor te stel dat dié roeping 'n omvattende roeping is wat ook die daaglikse werk van Christene insluit.

Die neiging om die Christelike roeping as 'n roeping tot geestelike of godsdienstige aktiwiteite te vereng is een wat dikwels in die geskiedenis van die kerk die botoon gevoer het. Ten grondslag daarvan lê 'n dualistiese beskouing van die geestelike en materiële wêrelde wat meer deur die Griekse filosofie geïnspireer is as deur die Bybel. In so 'n dualistiese beskouing word die materiële wêreld en alles wat daarmee saamhang, soos die liggaam, seksuele belewing en fisiese arbeid, as van mindere waarde, indien nie as boos nie, beskou. Verlossing behels - vanuit dié gesigspunt beskou - die 
(geleidelike) vrymaking uit die greep van materiële dinge tot 'n uitsluitlike gerigtheid op geestelike dinge.

So 'n dualistiese beskouing is volledig in stryd met die boodskap van die Bybel. Die boodskap van die Bybel is dat verlossing nie 'n losmaking van die gelowige van die materiële lewe tot ' $n$ suiwer geestelike lewe is nie. Dit behels eerder 'n omvattende herskepping van die skepping van God. Die verlossing wat Christus bewerkstellig het, behels die herstel en daarmee die herbevestiging van alles wat saamhang met God se goeie skepping. Dit hou, onder andere, ook die herbevestiging in van God se opdrag om te werk wat reeds voor die sondeval aan Adam en Eva gegee is. Volgens Genesis 2:15 was dit duidelik God se bedoeling met die skepping dat die mens die tuin van Eden sou bewerk. Genesis 1:28 praat selfs van 'n opdrag aan die mens om namens God beheer uit te oefen oor die natuurlike skepping - in die Christelike tradisie meestal aangedui as die "kulturele mandaat of opdrag" (vgl Stevens 1999:89-91). 'n Mens moet ongetwyfeld daarteen waak om Genesis 1:28 nie so te verstaan dat die uitbuiting van die natuurlike omgewing geregverdig word nie - soos dit in die verlede alte dikwels die geval was. Dit neem egter nie weg nie dat die beskouing dat God die mens as rentmeester aangestel het en dat dié aanstelling ook die opdrag tot die omvorming van die natuurlike omgewing deur werk insluit, Bybels gefundeerd is. Dit beteken ook dat werk as uitvoering van God se kultuuropdrag met reg as deel van die Christen se roeping deur God beskou kan word.

Om die gevaar van reduksie van die Christelike roeping tot slegs geestelike werk óf slegs kultuurwerk te vermy en reg te laat geskied aan die rykdom van die Bybelse beskouing van dié roeping, is dit waarskynlik die beste om met G R Preece die Christelike roeping as ' $n$ "drievoudige roeping" te omskryf (Preece 1998). Preece is van mening dat ons die volle reikwydte van dié roeping eers raaksien as ons ons in ag neem dat die Drieënige God daarin na ons kom as Vader, Seun en Gees. As Vader roep God ons tot 'n lewe in die volle werklikheid, in die geskiedenis. Dié lewe vra om omgee, regverdigheid en verantwoordelikheid, om meewerk aan die goeie lewe, vir alles en almal. As Seun roep God ons tot die Christelike lewe, tot geloof in Jesus Christus, tot blye aanvaarding van die boodskap van versoening, tot aanbiddende uitlewing daarvan as profete, priesters en konings. As Gees roep God ons tot 'n nuwe lewe, in die kerk en as getuies van 'n nuwe skepping, ' $n$ lewe waarin ons vra na ons eie gawes en geleenthede om deur die Gees gelei en gebruik te word. Aangesien die een roeping van God slegs tot ons kom in hierdie drieledige gestalte, mag ons nie slegs een aspek uitlig en die ander ignoreer nie. Aan hierdie drieledige roeping moet Christene op alle lewensterreine vashou, al is dit so dat bepaalde aspekte daarvan soms - 


\section{Durf ons nog preek dat werk 'n roeping van God is?}

afhangende van die betrokke lewensterrein - sterker geaksentueer sal word. So kan 'n mens verwag dat die eerste aspek waarin Christene tot deelname aan die volle werklikheid geroep word in die werkplek besondere klem sal ontvang. Dit beteken egter nie dat die ander aspekte geensins in die werkplek 'n rol hoef te speel nie.

'n Mens moet Volf toegee dat Luther beslis 'n te statiese en ook hiërargiese interpretasie van werk as roeping bied. Terselfdertyd oortuig Volf se afwysing van pogings om die beskouing van werk as roeping te herinterpreteer om dit meer toepaslik vir die snel veranderende werkplek in die hede te maak, ook nie. Hy probeer sulke pogings by voorbaat te diskwalifiseer deur te argumenteer dat 'n meer dinamiese interpretasie van werk as roeping nie sou klop met die enkelvoudigheid en permanensie van die algemene roeping tot die Christelike lewe nie. Indien hierdie Christelike roeping egter verstaan word as die een drieledige roeping wat in verskillende lewensituasies verskillende gestaltes kan aanneem, is dit nie nodig om daarvan uit gaan dat dié roeping in alle opsigte enkelvoudig en staties is nie. 'n Mens kan trouens die vraag stel of Volf se eie beskouing, naamlik dat die een algemene Christelike roeping uiteindelik vertak in 'n menigte gawes aan individue wat, onder andere, in die werkplek uitgeleef word, nie ook dui op die meervoudigheid en dinamiese karakter van die Christelike roeping nie. Wat Volf as gawes aandui, is eintlik maar die verskillende gestaltes wat die Christelike roeping in verskillende individue en in verskillende lewensituasies aanneem. As dit in orde is om 'n dinamiese interpretasie van werk as roeping te gee, is dit 'n vraag of dit enigsins nodig is om van die Reformatoriese tradisie af te wyk deur eerder ' $n$ ander Bybelse term te benut. Dié vraag is ook nodig, omdat die Bybelse term charisma ("gawe") hom nie so maklik leen om as sinoniem vir "konkretiseringe van die algemene Christelike roeping" aangewend te word nie. In die lig van Bybelse assosiasies val dit veel gemakliker om die gawes van die Gees eerder te verstaan as vermoëns of vaardighede wat deur die Gees aan individuele Christene geskenk word om hulle in staat te stel om hulle Christelike roeping in spesifieke lewensituasies, onder andere in die werkplek, te kan uitleef.

\section{RIGLYNE VIR PREDIKING OOR WERK}

Die gevolgtrekking waartoe tot dusver gekom is, is dat ons ook nog vandag behoort vas te hou aan die Reformatoriese beskouing dat werk 'n roeping van God is. Ons kan Luther se aanvanklike siening egter nie ongekwalifiseerd oorneem as ons reg wil laat geskied aan die meer dinamiese werkomgewing van ons tyd nie. Om vandag op 'n verantwoorde wyse oor werk as 'n roeping 
van God te preek, vra dat ten minste aan die volgende breë riglyne vasgehou word:

\subsection{Eerbiedig die totale heilshistoriese spektrum van die Bybelse boodskap oor werk}

Die versoeking om werk vanuit slegs een bepaalde heilshistoriese perspektief te belig, was en is nog steeds 'n reële een. Sommige teoloë neem werk slegs vanuit die perspektief van die skeppingsleer in oënskou en neig gevolglik om die status quo van werkinrigting te legitimeer. Ander met 'n meer piëtistiese inslag sluit aan by wat die Bybel sê oor die vloek oor werk as gevolg van die sondeval en neig om werk as 'n noodsaaklike euwel te beskou (Stott 1940:165). Nog ander, soos die kerkvaders, laat die lig uitsluitlik val op die heiligende uitwerking van werk en die implikasies van heiliging vir die gelowiges se instelling teenoor hulle werk (Volf 1991:71-73). Dit is egter eers as 'n mens vashou aan die hele heilshistoriese spektrum dat 'n mens reg kan laat geskied aan die rykdom van die Bybelse boodskap oor werk.

In die raamwerk van die skeppingsleer blyk dit dat God reeds voor die sondeval die mens as rentmeester oor sy skepping aangestel het. Alhoewel God self uitsluitlik verantwoordelik was vir die oorspronklike skepping van die heelal uit niks (creatio ex nihilo), betrek God die mens in die voortgaande skepping van die heelal (creatio continua). Hierdie betrokkenheid van die mens by die skepping is tradisioneel as bewaring (preservatio), na analogie van God se bewarende en voorsienige betrokkenheid by die skepping, beskou (vgl. Volf 1993:98-99). Deur werk lewer die mens diens aan God in die uitoefening van sy voorsienige sorg en daarmee ook aan medemense en die natuurlike skepping. Die klem wat vandag ook op die verantwoordelikheid tot kreatiewe ontwikkeling van die skepping gelê word, hoef nie daarmee in stryd te wees nie. Die assosiasie van kreatiwiteit is deel van die verantwoordelikheid tot voortgaande skepping. Hierdie verantwoordelikheid tot kreatiwiteit moet egter steeds in ewewig met die verantwoordelikheid tot bewaring, dit wil sê, tot oordeelkundige bestuur en instandhouding van die natuurlike omgewing gehou word. Dit is ook nie verkeerd om uit die boodskap dat werk deel van die oorspronklike skeppingsbedoeling van God vir die mens was, af te lei dat die mens ook in die werk tot ontplooiing kom nie (Stott 1990:166167). Om egter op grond daarvan te beweer dat die mens by uitstek in werk tot selfverwesenliking kom, sou neerkom op 'n onregmatige legitimering van hedendaagse opvattinge oor die betekenis van werk.

In die lig van wat die Bybel leer oor die sondeval moet enige optimistiese oorskatting van die betekenis van werk of van dit wat deur werk bereik kan word, afgewys word. Die sondeval en ook die vloek oor die mens 


\section{Durf ons nog preek dat werk 'n roeping van God is?}

as gevolg daarvan het ' $n$ ingrypende versteuring ook in mense se instelling tot werk en tot die werkverhoudinge waarin hulle staan, gebring. Daar is in hulle houding teenoor hulle werk 'n neiging tot uiterstes: tot onderwaardering van die betekenis van werk en tot werkskuheid of tot oorwaardering en tot werkverslawing (Stott 1990:166-168). In plaas daarvan om God en medemense deur hulle werk te dien en hulle werk so te doen dat die integriteit van die natuurlike skepping bewaar word, neig hulle daartoe om slegs hulle eiebelang te bevorder en om hulle medemense en die natuurlike omgewing uit te buit.

Aangesien die verlossing in Jesus Christus die herstel van God se goeie skepping insluit, open dit ook die weg vir die herstel van God se skeppingsbedoeling met werk. In navolging van Christus kan 'n gesonde instelling tot werk ontwikkel word en is dit moontlik om deur werk diens aan God, aan medemense en die natuurlike omgewing te lewer. Aangesien die Bybel leer dat die finale oorwinning oor die sonde eers met die wederkoms van Christus sal geskied, moet gelowiges egter steeds waak teen 'n verkeerde instelling tot hulle werk en teen verkeerde motiewe in die uitoefening van hulle werk. Hulle moet ook daarmee rekening hou dat hulle werk negatiewe gevolge kan hê en dat die strukture waarbinne hulle werk nog steeds onregverdig kan wees. Aangesien verlossing ook dissipelskap van Christus en inlywing in die kerk as liggaam van Christus behels, hou dit meer as net 'n herstel van God se oorspronklike skeppingsbedoeling met werk in. Dit behels inskakeling by ' $n$ omvattende Christelike bediening in navolging van Christus in die kerk en in die wêreld.

Die interpretasie wat gelowiges heg aan wat die Bybel leer oor die eindtyd (eschaton), kan ingrypende implikasies hê vir hoe hulle die kultuurtaak en hulle eie daaglikse werk verstaan. Indien daarvan uitgegaan word dat die Bybel leer dat die wederkoms van Christus gepaard sal gaan met 'n vernietiging (annihilatio) van die skepping, is die afleiding onvermydelik dat alles wat mense in die uitoefening van hulle kultuuropdrag tot stand gebring het, geen standhoudende betekenis het nie, maar gedoem is tot vernietiging. Dit is dan hoogstens die geestelike werk wat iemand in die verkondiging van die evangelie en die instandhouding van die kerk gedoen het wat standhoudende betekenis kan hê. Op grond van wat die Bybel oor die "nuwe aarde en die nuwe hemel" wat met die wederkoms van Christus kom en oor die liggaamlike opstanding van die dooies leer, is dit egter meer konsekwent om te aanvaar dat die skepping en ook die resultaat van menslike kultuurwerk in die eindtyd nie vernietig sal word nie, maar eerder getransformeer sal word (vgl Volf 1991:89-92). Dit sal, met ander woorde, in 'n gesuiwerde vorm bewaar word. Indien dit egter so is, beteken dit dat menslike kultuurwerk wel 
standhoudende betekenis kan hê. Dit beteken ook dat dit sinvol vir Christene is om hulle reeds nou te beywer vir die transformasie van werk en werkstrukture om dit meer in ooreenstemming met die geopenbaarde wil van God te bring.

\subsection{Neem in ag dat werk as roeping van God deur die opdrag van God tot aanbidding en rus begrens word}

In beide die Joodse en Christelike godsdienste speel die vierde gebod 'n sentrale rol. Opvallend is dat in hierdie gebod nie 'n opdrag tot werk gegee word nie - die doen van werk word eerder as vanselfsprekend aanvaar maar 'n opdrag tot rus van werk met die oog op aanbidding van God (vgl Stevens 1999:37-38, 92; Vischer 1996:68-70). Die bedoeling van die vierde gebod is duidelik: werk mag nie al 'n mens se tyd in beslag neem nie. Daar moet gereelde tye wees wanneer 'n mens jou werk aflê om ruimte te skep vir die aanbidding van God, ook vir die aanbidding van God saam met ander gelowiges. Hierdie geleentheid tot aanbidding van God moet ook aan ander mense gegun word, ook vir diegene wat vir jou werk.

Die bedoeling van die vierde gebod is egter nog meer radikaal. Dit is nie slegs 'n geval van dat gelowiges ook vir die aanbidding van God, naas hulle werk, tyd en ruimte moet skep nie. Lees 'n mens dié gebod in samehang met die eerste gebod sê dit ook dat werk nie die belangrikste ding in 'n mens se lewe mag wees nie. Die aanbidding van God moet die eerste plek in 'n mens se lewe beklee (vgl Barth 1951:683-744; Stott 1990:166-168). God het die mens in die eerste plek geskape om in gemeenskap met God te lewe. Daarom is dit nie genoeg om slegs op sekere dae, op sekere tye, aandag te gee aan die aanbidding van God nie. Die hele lewe van die gelowige moet in die teken staan van gemeenskap met en aanbidding van God.

Die implikasies van die vierde gebod vir hedendaagse Christene se benadering tot werk is ingrypend. In die eerste plek behoort hulle in hierdie tyd waarin daar die neiging bestaan om van Sondag maar net nog 'n werkdag te maak, juis erns te maak met Sondag as 'n dag van aanbidding. Dit beteken nie maar net dat hulle die geleentheid tot gesamentlike aanbidding in hulle gemeentes en ander geleenthede wat die Sondag tot belewing van gemeenskap met God bied, sal benut nie, maar ook dat hulle sal stry teen pogings in die samelewing om Sondag 'n sewende werkdag te maak. Tweedens behoort Christene ook hulle werk as aanbidding van God te beskou (vgl Wainwright 2001:33-41). Dit beteken nie dat hulle soos Thomas Carlyle moet aanvaar dat werk vanselfsprekend aanbidding van God is nie (laborare est orare). Om dit te doen, is om weer aan werk 'n belangrikheid toe te ken wat dit nie toekom nie. Dit beteken eerder dat Christene sal aanvaar 


\section{Durf ons nog preek dat werk 'n roeping van God is?}

dat die gemeenskap met en aanbidding van God voorop behoort te staan en elke aspek van hulle lewens, ook hulle werk, behoort te deursuur. Hulle werk kan egter alleen deursigtig word as nog 'n manier om God te aanbid as hulle hulle werk doen in ooreenstemming met God se morele wil en hulle nie gedwing word om in stryd daarmee hulle werk te doen nie. Daarmee is nog 'n implikasie van die vierde gebod vir hedendaagse Christene gegee: hulle mag nie werk doen wat in stryd is met God se wet nie en hulle moet stry teen werkpraktyke wat in stryd is daarmee.

Alhoewel die opdrag tot rus van werk in die vierde gebod in die eerste plek met die skep van ruimte vir en die toekenning van prioriteit aan die aanbidding van God te doen het, is met reg in die kerkgeskiedenis afgelei dat dié gebod ook klem lê op die belang van die gereelde afwisseling van werk deur rus as 'n onontbeerlike manier vir mens en dier om tot verhaal te kom. Die gebod gee uitdrukking aan die oortuiging dat rekreasie ook vir die mens van groot belang is (vgl Meilaender 2000:233-268; Pieper 1993; Volf 1991:133-141). Wanneer mense die natuurskoon geniet, met hulle gesin en vriende verkeer, 'n maaltyd geniet, sport beoefen en slaap word belangrike menslike behoeftes vervul waarsonder 'n liggaamlik en psigies gesonde lewe nie moontlik is nie.

\subsection{Erken die omvattende aard van die Christelike roeping en van werk as roeping}

Ons het reeds gelet op Preece se omskrywing van die Christelike roeping as 'n omvattende drievoudige roeping wat van die Vader, die Seun en die Gees uitgaan. Hierdie drievoudige roeping stempel ook die Christen se werk as roeping, maar strek wyer as sy werk. Die Kanadese teoloog R S Stevens bied 'n ander omskrywing van die omvattende roeping van God wat na sy mening eweseer drievoudig van aard is: die roeping om aan God te behoort deur 'n dissipel van Christus te word, waardeur die gemeenskap met God herstel word; die roeping om die volk van God te wees, waardeur gemeenskap tussen mense herstel word, in die eerste plek in die kerk, maar ook in die groter menslike gemeenskap (die gesin, buurt, stad, nasie en wêreldgemeenskap) en die roeping om die werk van God te doen wat medeskepperskap herstel deur te help om God se wêreld te laat werk deur die verskillende maniere waarop ons as rentmeesters op aarde diens lewer, maar ook deur getuienis af te lê van die evangelie, omdat dit die doel van die Christelike roeping is dat mense gemeenskap met God sal hê deur Jesus Christus (Stevens 1999:88). Ook in hierdie omskrywing van die Christelike roeping - wat nie in stryd is met Preece se omskrywing nie - blyk dit dat dié roeping wyer strek as die werk van die Christen. 
Wat ook uit Stevens se omskrywing van die Christelike roeping blyk, is dat werk as roeping veel meer omvat as die roeping om as Christen die werk waarvoor jy betaal word, te doen (vgl ook Preece 1995:250-251; Stott 1990:180-181). 'n Christen help nie net om God se wêreld te laat werk deur die werk waarvoor hy of sy betaal word te doen nie. Ook die huisvrou wat haar kinders opvoed en die huishouding bestuur, speel ' $n$ onontbeerlike rol in dié verband. Daar is egter ook belangrike vrywilligerwerk in onder andere siekeversorging, welsynsorganisasies, organisasies wat omgewingsbewaring bevorder, skole en politieke partye. Baie van dié werk word deur mense gedoen wat nie ' $n$ vaste werk in die formele sektor het nie. Hulle kan egter, in die streng sin van die woord, nie as werkloos geklassifiseer word nie. Ook diegene wat wel 'n vaste werk het, het 'n roeping tot werk wat verder strek as die werk waarvoor hulle betaal word. Die man of vrou wat 'n vaste werk het, ontkom nie aan die verantwoordelikheid tot die opvoeding van hulle kinders en tot betrokkenheid by vrywilligerwerk in die samelewing nie.

Alle Christene het daarby ook die verantwoordelikheid om getuies van die evangelie van Jesus Christus te wees. Hulle kan en behoort hierdie getuieniswerk uit te oefen in allerlei kerklike bedieninge. Hulle kan en behoort dit egter ook te doen deur die ywerige en eerlike manier waarop hulle hulle daaglikse werk doen en deur die gesindheid van respek en welwillendheid wat hulle teenoor kollegas en kliënte openbaar.

\subsection{Die prediking oor werk behoort priesterlik, koninklik en profeties van aard te wees}

In die inleiding is daarop gewys dat baie lidmate nie behoefte daaraan het om in die prediking te verneem wat hulle verantwoordelikhede as Christene in hulle werk is nie. Hulle soek eerder ontlading van die stres wat hulle in die werkplek ervaar en genesing van die psigiese wonde wat hulle in die kompeterende werksituasie opdoen. In die Suid-Afrikaanse konteks is daar as gevolg van die steeds dreigende aflegging van werknemers as gevolg van 'n wêreldwye tendens tot die rasionalisering van werkkragte, die druk wat mense uit voorheen benadeelde groepe ervaar wat nou vir die eerste keer bestuursposte beklee, maar ook as gevolg van regstellende aksie in dié verband ' $n$ groot behoefte onder lidmate. Die erediens behoort so ingeklee te wees dat lidmate die geleentheid tot emosionele ontlading het en die vertroostende en genesende genade van God kan ervaar. Ook die prediking behoort hierdie priesterlike aard te hê, ook al verwys die prediker nie uitdruklik na die werksituasie van lidmate nie.

Die prediking kan wat die werk van lidmate betref, egter nie volstaan met priesterlike vertroosting nie. Dit moet lidmate ook toerus om as konings te 


\section{Durf ons nog preek dat werk 'n roeping van God is?}

oorwin oor die sonde en die negatiewe in hulle werkplek. Die toerusting kan geskied deur toeligting van die betekenis van werk as roeping van God, sodat lidmate kan glo dat God hulle in hulle werk geplaas het om hulle gawes en die geleenthede wat hulle werk bied, te benut om God en hulle naaste te dien. 'n Duidelike besef van die geloofsbetekenis van hulle werk het menige Christen al in staat gestel om die mees onaangename werksomstandighede met 'n positiewe gesindheid te benader.

Dié toerusting kan en behoort egter ook te geskied deur aan lidmate voor te hou wat hulle verantwoordelikhede is as hulle hulle werk as roeping wil uitleef. ' $n$ Eerste verantwoordelikheid is sekerlik om die geleentheid wat hulle werk hulle bied om getuies van die evangelie van Jesus Christus in woord en in daad te wees, daadwerklik te benut. 'n Tweede verantwoordelikheid is om ook in die uitoefening van hulle werk steeds getrou te bly aan hulle morele oortuiginge as Christene. In die uitoefening van hulle werk deel hulle ook in die kultuurtaak wat God aan mense opgedra het. Daarom het hulle ook 'n derde verantwoordelikheid om hulle werk so effektief en professioneel as moontlik te doen.

Predikers behoort sensitief te wees vir spanninge tussen hierdie drie verantwoordelikhede wat vandag deur baie lidmate ervaar word. Die probleem is veral dat in baie werkplekke die klem feitlik uitsluitlik op die derde verantwoordelikheid val. Die verantwoordelikheid om so effektief en produktief as moontlik te werk, het dikwels prioriteit bo en word soms heeltemal losgemaak van die verantwoordelikheid om moreel reg op te tree in die werkplek. Die druk wat lidmate ervaar om in bepaalde werksituasies teen hulle eie morele oortuigings in op te tree, is dikwels besonder sterk. Predikers moet waak teen die versoeking om in reaksie presies die teenoorgestelde standpunt in te neem en lidmate te vermaan om eenvoudig altyd voorrang aan Christelike morele waardes te gee, maak nie saak wat die gevolge is nie. Hulle moet lidmate eerder help om 'n weg te vind om sowel Christelike morele waardes, as waardes soos effektiwiteit en produktiwiteit, in hulle werk tot hulle reg te laat kom. 'n Tweede probleem wat lidmate ervaar, is dat wanneer 'n gedragskode in hulle werkplek as riglyn vir al die werknemers aanvaar word, hierdie kode dikwels op 'n algemene konsensus berus wat tekortskiet aan die morele waardes wat ' $n$ mens as Christen daarop nahou. Hulle kom dan voor die situasie te staan dat hulle met twee morele mate moet meet: een vir sigself as Christen en een vir die ander werknemers. Weer eens moet predikers nie oorvereenvoudigde oplossings aan lidmate voorhou en gedragskodes en professionele kodes afspeel teenoor Christelike waardes nie. Die belangrike rol wat sulke kodes in veral die Suid-Afrikaanse werkplek, wat deur kulturele en godsdienstige pluraliteit gekenmerk word, in die 
bestryding van bedrog en korrupsie kan speel, moet erken word. Terselfdertyd moet lidmate op hulle eie verantwoordelikheid om trou te bly aan Christelike morele waardes en om hulle te beywer om die morele konsensus in die werkplek meer in ooreenstemming met sulke morele waardes te bring, gewys word.

Die prediking oor werk as roeping moet ten slotte ook profeties van aard wees. Ons besef vandag beter as Luther dat werkstrukture deel in die gebrokenheid as gevolg van die sondeval en daarom transformasie en vernuwing benodig om dit meer in ooreenstemming die eskatologiese bedoeling van God met sy skepping te bring (vgl Estey 2002:118-140; Task Force UPCUSA 1990:57-111; Volf 1991:88-122). Lidmate behoort ook deur die prediking toegerus te word om as profete in hulle werkplek op te tree en by te dra tot die transformasie daarvan. Soms is bepaalde wanpraktyke in die werkplek so wydverspreid en hardnekkig dat ook in die prediking profeties daarteen kritiek gelewer moet word.

\section{GEVOLGTREKKING}

Die vraag: "Durf ons vandag nog preek dat werk 'n roeping van God is?" is in die artikel aan die orde gestel. 'n Aantal faktore wat daartoe bydra dat die siening van Luther en Calvyn dat werk 'n roeping van God is, vandag as problematies ervaar word, is uitgewys. Hierdie faktore, meen 'n teoloog soos Miroslav Volf, noop ons daartoe om afskeid te neem van die Hervormers se siening. In die artikel word egter geargumenteer dat dit nie nodig is om die siening dat werk 'n roeping van God is te laat vaar nie, mits ons hierdie roeping meer dinamies as Luther verstaan om reg te laat geskied aan hedendaagse ontwikkelinge ten aansien van werk en ons dit binne 'n breër teologiese raamwerk plaas om reg te laat geskied aan die verbande waarin werk in die Bybel geplaas word. ' $n$ Aantal riglyne vir prediking oor werk is geformuleer om gestalte te gee aan so 'n eietydse verstaan van werk as 'n roeping van God.

\section{Literatuurverwysings}

Barth, K 1951. Kirchliche Dogmatik, III/4. Zürich: EVZ-Verlag.

Bellah, R N 1990. Discipleship and citizenship in the workplace. Pasadena, CA: Fuller Theological Seminary.

Botha, J G (ed) 2001. Work as calling and worship: Challenging thoughts for our day. Wellington: Lux Verbi.

Estey, K 2002. A new Protestant labor ethic at work. Cleveland, $\mathrm{OH}$ : The Pilgrim Press.

Forrester, W R 1951. Christian vocation: Studies in faith and work. New York: Charles Scribner's Sons. 


\section{Durf ons nog preek dat werk 'n roeping van God is?}

Grenholm, C-H 1993. Protestant work ethics: A study of work ethical theories in contemporary Protestant theology. Uppsala: University of Uppsala.

Meilaender, G C 2000. Working: Its meaning and its limits. Notre Dame, IN: University of Notre Dame.

Nelson, J O (ed) 1954. Work and vocation: A Christian discussion. New York: Harper and Row.

Pieper, J 1963. Leisure: The basis of culture. New York: Random House.

Preece, G R 1995. Changing work values: A Christian response. Melbourne: Acorn Press.

Preece, G R 1998. The viability of the vocation tradition in trinitarian, creedal and reformed perspective: The threefold call. Lewiston: The Edwin Mellen Press.

Rossouw, D 2002. Business ethics in Africa. Cape Town: Oxford University Press Southern Africa.

Schuurman, D 2001. Can a job be a calling in a sinful society? in J G Botha (ed), Work as calling and worship: Challenging thoughts for our day, 46-70. Wellington: Lux Verbi.

Smit, D 2001. Church and work? Questions concerning the Christian view of calling, in J G Botha (ed), Work as as calling and worship: Challenging thoughts for our day, 9-32. Wellington: Lux Verbi.

Stevens, R P 1999. The other six days: Vocation, work, and ministry in Biblical perspective. Grand Rapids, MI: Eerdmans.

Stott, J 1990. Issues facing Christians today: New perspectives on social and moral dilemmas. Collins: London.

Task Force on Issues of Vocation and Problems at Work in the United States, PCUSA 1990. Vocation and work: Challenges in the workplace. Louisville, KY: Committee on Social Witness Policy, Presbyterian Church (USA).

Van der Ven, J A 1993. Ecclesiologie in context. Kampen: Kok.

Vischer, L 1996. Arbeit in der Krise: Theologische Orientierungen. Neukirchen-Vluyn: Neukirchener Verlag.

Volf, M 1991. Work in the Spirit: Toward a theology of work. New York: Oxford University.

Wainwright, G 2001. Liturgy and labour: Prayer and work in the Christian tradition, in J G Botha (ed), Work as calling and worship: Challenging thoughts for our day, 33-41. Wellington, Lux Verbi. 